\title{
A contribution to the identification of charcoal origin in Brazil II - Macroscopic characterization of Cerrado species
}

\author{
THAÍS A.P. GONÇALVES ${ }^{1}$, SILVANA NISGOSKI ${ }^{1}$, JULIA S. OLIVEIRA ${ }^{2}$, CARMEN \\ R. MARCATI ${ }^{3}$, ADRIANO W. BALLARIN ${ }^{4}$ and GRACIELA I.B. MUÑIZ ${ }^{1}$ \\ ${ }^{1}$ Universidade Federal do Paraná, Departamento de Engenharia e Tecnologia Florestal, Av. \\ Pref. Lothário Meissner, 900, Jardim Botânico, 80210-170 Curitiba, PR, Brasil \\ ${ }^{2}$ Universidade de Brasília, Campus Universitário Darcy Ribeiro, Instituto de \\ Ciências Biológicas, Asa Norte, 70910-900 Brasília, DF, Brasil \\ ${ }^{3}$ Universidade Estadual Paulista/UNESP, Departamento de Ciências Florestais, Fazenda \\ Lageado, Rua José Barbosa de Barros, 1780, 18603-970 Botucatu, SP, Brasil \\ ${ }^{4}$ Universidade Estadual Paulista/UNESP, Departamento de Engenharia Rural, Fazenda Lageado, \\ Rua José Barbosa de Barros, 1780, Caixa Postal 237, 18603-970 Botucatu, SP, Brasil \\ Manuscript received on May 13, 2015; accepted for publication on July 17, 2015
}

\begin{abstract}
The Brazilian Cerrado is the richest savanna in the world. It is also one of the biomes more threatened in the country and a hotspot for conservation priorities. The main causes of deforestation in Cerrado are agricultural practices, livestock and charcoal production. Although charcoal has a minor impact, its consumption represents the deforestation of $16.000 \mathrm{Km}^{2}$ of the Cerrado. To contribute for the biomes's conservation it is very important to improve forestry supervision. Thus, in this work we present the macroscopic characterization of charcoal from 25 Cerrado's species. We simulate the real conditions of forest controllers by using the magnifications of $10 x, 25 x$ and $65 x$. Likewise, the charcoals micrographs are all of transverse sections due to the larger amount of anatomical information. We also analyzed texture, brightness, vitrification, ruptures and some special features. The species present several differences in their anatomical structure. Although some of them are very unique, this work does not intent to identify charcoals only by macroscopic analyses. But it might give directions to future identification of genera or species. It also provides knowledge for government agents to verify the documents of forestry origin by fast analyzing a sample of charcoal itself.
\end{abstract}

Key words: charcoal anatomy, nature conservancy, forest control, native species.

\section{INTRODUCTION}

The Brazilian Cerrado is considered the richest savanna in the world, but it is one of the biomes more threatened in the country (MMA 2011). It is considered a hotspot for conservation priorities; it has 4,400 endemic plants which correspond $1.5 \%$

Correspondence to: Thaís Alves Pereira Gonçalves

E-mail: th_goncalves@yahoo.com.br of global endemic flora (Myers 2000). Also, the Cerrado sensu lato contains 11,806 plant species occurring in (Lista de Espécies da Flora do Brasil 2014) representing $5 \%$ of the biodiversity in the world (MMA 2011).

The main causes of deforestation in Cerrado are: (i) agricultural practices; (ii) livestock; (iii) charcoal (MMA 2011). Historically, the massive occupancy of the biome began in 1920 due to 
the coffee industry; around ten years later, the government promoted grants and technical assistance to livestock farming (Klink and Moreira 2002). It resulted in approximately $50 \%$ of Cerrado's area converted to agriculture and livestock (Klink and Machado 2005). To "contribute" with this reality there is the charcoal production.

Brazil is the world's largest producer of charcoal (FAO 2012). Almost $90 \%$ of charcoal goes to the iron and steel industry (Brasil 2012). Our country remains the only one producing iron from charcoal; comparing with coal, the iron from charcoal has better quality and does not contribute to environmental pollution (ABRAF 2013).

One of the worst problems of charcoal production is the illegal cutting of native species which is evaluated $30-35 \%$ of total output (IBGE 2010, ABRAF 2012). In 2005 almost $35 \%$ of native charcoal was produced from Cerrado's species (Duboc et al. 2007). Also, the charcoal consumption represents the deforestation of approximately 1,6 million hectares or $16,000 \mathrm{Km}^{2}$ of the Cerrado (MMA 2011).

In this context, the challenges for cerrado's conservation are especially: (i) illegal logging; (ii) counterfeiting documents, such as "document of forestry origin" (DOF); (iii) reforestation highly deficit; (iv) reinforcements in/applications of environmental laws; (v) difficult to make viable forest management Cerrado (MMA 2011). The Brazilian Government already did a voluntary national commitment to reduce $40 \%$ of the annual rates of deforestation in the Cerrado (Brasil 2013). To accomplish these goals, it is very important to improve forestry supervision.

To help the charcoal control, in this work we present the macroscopic characterization of 25 Cerrado species's carbonized. Also, we give some explanations about how the analysis must be done. It is essentially justified by: (i) importance of Cerrado; (ii) the need to identify illegal charcoal; (iii) provide knowledge for government agents to verify the DOF by fast analyzing a sample of charcoal itself.

\section{MATERIALS AND METHODS}

The species analyzed were: 1 - Lithrea molleoides (Vell.) Engl. (Anacardiaceae); 2 - Annona crassiflora Mart. (Annonaceae); 3 - Gochnatia polymorpha (Less.) Cabrera (Asteraceae); 4 Tabebuia aurea (Silva Manso) Benth. \& Hook. f.ex S. Moore (Bignoniaceae); 5 - Cordia sellowiana Cham. (Boraginaceae); 6 - Caryocar brasiliense A. St.-Hil. (Caryocaraceae); 7 - Terminalia glabrescens Mart. (Combretaceae); 8 -Lamanonia ternata Vell. (Cunoniaceae); 9 - Anadenanthera peregrina var. falcata (Benth.) Reis (FabaceaeMimosoideae); 10 - Copaifera langsdorffii Desf. (Fabaceae-Caesalpinoideae); 11 - Leptolobium elegans Vogel (Fabaceae-Papilionoideae); 12 Ocotea corymbosa (Meisn.) Mez (Lauraceae); 13 - Eriotheca gracilipes (K. Schum.) A. Robyns (Malvaceae); 14 - Microlepis oleifolia (DC.) Triana (Melastomataceae); 15 - Ficus guaranitica Chodat (Moraceae); 16 - Myrcia bella Cambess. (Myrtaceae); 17 - Guapira noxia (Netto) Lundell (Nyctaginaceae); 18 -Ouratea spectabilis (Mart. ex Engl.) Engl. (Ochnaceae); 19 - Myrsine umbellata G. Don (Primulaceae); 20 - Roupala montana Aubl. (Proteaceae); 21 - Tocoyena formosa (Cham. \& Schltd1.) K. Schum. (Rubiaceae); 22 - Siparuna brasiliensis (Spreng.) A. DC. (Siparunaceae); 23 - Styrax ferrugineus Nees \& Mart. (Styracaceae); 24 - Symplocos pubescens Klotzsch ex Benth. (Symplocaceae); 25 - Vochysia tucanorum Mart. (Vochysiaceae). One to three individuals of each species were analyzed.

The wood samples were collected in a 180 ha private reserve of Cerrado sensu lato "Fazenda Palmeira da Serra" in São Paulo State, Brazil (23 ${ }^{\circ} 02^{\prime}$ 55.5" S and 48 31' 26.1"W). Discs over three-cmthick were obtained from the basal portion of the most developed branches. Vouchers were deposited in the herbarium 'Irina Delanova de Gemtchujini- 
cov' (BOTU) of the "Instituto de Biociências" (IB). The wood samples were deposited in the wood collection 'Maria Aparecida Mourão Brasil' (BOTw) of the Universidade Estadual Paulista (UNESP) - Faculdade de Ciências Agronômicas (FCA) in Botucatu, São Paulo State.

The carbonization process lasted $5 \mathrm{~h}$, with a final temperature of $450^{\circ} \mathrm{C}$ and heating rate of $1.66^{\circ} \mathrm{C} /$ min; the samples remained at the final temperature for $2 \mathrm{~h}$ (Muñiz et al. 2012). The resulting charcoal samples were manually broken and analyzed with a Zeiss Discovery V12 stereomicroscope according Gonçalves et al. (2014). The charcoal samples were deposited at the charcoal collection of 'Laboratório de Anatomia e Qualidade da Madeira' of Universidade Federal do Paraná (LANAQM/ UFPR) in Curitiba, Paraná State.

We use the recommendations of the IAWA Committee (1989) for descriptions and measurements. Also, others references for macroscopic wood analysis were used (e.g. Botosso 2009, FPL
2010). The vitrification degrees were analyzed according Marguerie and Hunot (2007).

The charcoals micrographs are all of transverse section, because this section has more information about the species. Also due to practical use, as forest controllers normally have portable magnifier glasses that do not allow higher magnifications needed to observe the longitudinal sections. Figure 1 has micrographs with bars of $1 \mathrm{~mm}$; the magnifications are $10 \mathrm{x}$, simulating the most common portable magnifier glasses of forest controllers. Figure 2 has higher magnifications aiming to show some details; the bars are 100 and $200 \mu \mathrm{m}$; the magnifications are $25 \mathrm{x}, 65 \mathrm{x}$ and $100 \mathrm{x}$, simulating better portable magnifier glasses that can be easily find in specialized markets.

\section{RESULTS}

The Table I shows the most important anatomical features to aid in charcoal identification.

TABLE I

Growth rings and anatomical features of the species studied. Numbers are related to the figures presented above. GR $=$ growth rings. $a=$ fiber zones. $b=$ marginal lines/bands of axial parenchyma. $c=$ semi-ring porosity. $d=$ marked $b y$ closeness of the narrow bands of scalariform parenchyma. $e=$ variations within growth layers in the axial parenchyma, where the long aliform confluent parenchyma tends to form irregular bands. $-=$ absent or indistinct. $\emptyset=$ vessel tangential diameter. $\mathbf{F b}=$ Fibers. WT $=$ fiber wall thickness. $\mathrm{MI}=$ mineral inclusions. $\checkmark=$ present. $($ ) $=$ rare or few. $-=$ absent. $T x=$ Texture. $f(=$ fine. md $=$ medium. $c o=$ coarse. $f b=$ fibrous. The parenchyma type with $(*)$ is best seen in higher magnification. The results are presented as mean values (minimum-maximum), standard deviation.

\begin{tabular}{|c|c|c|c|c|c|c|c|c|}
\hline \multirow[t]{2}{*}{ Character } & \multirow{2}{*}{ GR } & \multicolumn{2}{|c|}{ Vessels } & \multirow{2}{*}{$\begin{array}{c}\text { Axial parenchyma } \\
\text { Type }\end{array}$} & \multirow{2}{*}{$\begin{array}{c}\text { Rays } \\
\mathrm{N}^{\mathrm{o}} \text { per } \mathrm{mm}\end{array}$} & \multirow{2}{*}{$\frac{\mathbf{F b}}{\mathrm{WT}(\mu \mathrm{m})}$} & \multirow{2}{*}{ MI } & \multirow{2}{*}{$\mathbf{T x}$} \\
\hline & & $\varnothing(\mu \mathrm{m})$ & $\mathrm{N}^{\mathrm{o}}$ per $\mathrm{mm}^{2}$ & & & & & \\
\hline Lithrea molleoides & $\mathrm{a}$ & $\begin{array}{c}48 \\
(35-67) \\
9\end{array}$ & $\begin{array}{c}67 \\
(55-81) 8\end{array}$ & vasicentric, confluent & $\begin{array}{c}10 \\
(6-14) \\
2\end{array}$ & 3 & $\checkmark$ & md-co \\
\hline Annona crassiflora & a & $\begin{array}{c}71 \\
(49-101) \\
12\end{array}$ & $\begin{array}{c}26 \\
(20-40) 6\end{array}$ & lines, scalariform & $\begin{array}{c}6 \\
(5-9) \\
1\end{array}$ & 2 & $(\checkmark)$ & md \\
\hline Gochnatia polymorpha & $\mathrm{a}$ & $\begin{array}{c}35 \\
(22-47) \\
5\end{array}$ & $\begin{array}{c}31 \\
(19-42) 6\end{array}$ & confluent, vasicentric & $\begin{array}{c}9 \\
(6-10) \\
1\end{array}$ & 3 & - & fi-md \\
\hline Tabebuia aurea & $\mathrm{b}$ & $\begin{array}{c}64 \\
(44-91) 14\end{array}$ & $\begin{array}{c}63 \\
(47-79) 12\end{array}$ & $\begin{array}{l}\text { vasicentric, lozenge-aliform, } \\
\text { confluent, bands, marginal }\end{array}$ & $\begin{array}{c}12 \\
(9-14) \\
2\end{array}$ & 3 & - & md \\
\hline Cordia sellowiana & $\mathrm{b}, \mathrm{c}$ & $\begin{array}{c}73 \\
(47-149) \\
22\end{array}$ & $\begin{array}{c}30 \\
(20-42) 6\end{array}$ & bands, confluent, vasicentric & $\begin{array}{c}8 \\
(7-9) \\
1\end{array}$ & 2 & $\checkmark$ & fi-md \\
\hline
\end{tabular}


TABLE I (continuation)

\begin{tabular}{|c|c|c|c|c|c|c|c|c|}
\hline \multirow[t]{2}{*}{ Character } & \multirow{2}{*}{ GR } & \multicolumn{2}{|c|}{ Vessels } & \multirow{2}{*}{$\begin{array}{c}\text { Axial parenchyma } \\
\text { Type }\end{array}$} & \multirow{2}{*}{$\frac{\text { Rays }}{\mathrm{N}^{\mathrm{o}} \text { per } \mathrm{mm}}$} & \multirow{2}{*}{$\frac{\mathbf{F b}}{\mathrm{WT}(\mu \mathrm{m})}$} & \multirow{2}{*}{ MI } & \multirow{2}{*}{$\mathbf{T x}$} \\
\hline & & $\varnothing(\mu \mathrm{m})$ & $\mathrm{N}^{\mathrm{o}}$ per $\mathrm{mm}^{2}$ & & & & & \\
\hline Caryocar brasiliense & $\mathrm{a}, \mathrm{b}$ & $\begin{array}{c}66 \\
(51-78) \\
7\end{array}$ & $\begin{array}{c}37 \\
(33-44) 3\end{array}$ & $\begin{array}{c}\text { diffuse, diffuse-in-aggregates, } \\
\text { marginal lines }\end{array}$ & $\begin{array}{c}12 \\
(8-15) \\
2\end{array}$ & 2 & $\checkmark$ & md \\
\hline Terminalia glabrescens & a & $\begin{array}{c}73 \\
(50-109) \\
16\end{array}$ & $\begin{array}{c}30 \\
(22-36) 5\end{array}$ & $\begin{array}{l}\text { lozenge-aliform, confluent, } \\
\text { vasicentric }\end{array}$ & $\begin{array}{c}16 \\
(12-18) \\
2\end{array}$ & 3 & - & $\mathrm{co}-\mathrm{fb}$ \\
\hline Lamanonia ternata & a & $\begin{array}{c}48 \\
(31-60) \\
6\end{array}$ & $>100$ & diffuse-in-aggregates* & $\begin{array}{c}15 \\
(13-18) \\
2\end{array}$ & 2 & $\checkmark$ & fi-md \\
\hline $\begin{array}{l}\text { Anadenanthera } \\
\text { peregrina var. falcata }\end{array}$ & $\mathrm{b}$ & $\begin{array}{c}60 \\
(44-81) \\
9\end{array}$ & $\begin{array}{c}38 \\
(28-47) 6\end{array}$ & $\begin{array}{l}\text { vasicentric, lozenge-aliform, } \\
\text { confluent, marginal }\end{array}$ & $\begin{array}{c}9 \\
(8-11) \\
1\end{array}$ & $2-3$ & $\checkmark$ & md \\
\hline Copaifera langsdorffii & $\mathrm{b}$ & $\begin{array}{c}75 \\
(53-98) 12\end{array}$ & $\begin{array}{c}27 \\
(18-38) 7\end{array}$ & $\begin{array}{l}\text { marginal, vasicentric, lozenge- } \\
\text { aliform }\end{array}$ & $\begin{array}{c}11 \\
(8-14) \\
2\end{array}$ & 2 & $\checkmark$ & fi-md \\
\hline Leptolobium elegans & $\mathrm{b}$ & $\begin{array}{c}51 \\
(31-65) \\
9\end{array}$ & $\begin{array}{c}56 \\
(43-68) 8\end{array}$ & $\begin{array}{l}\text { vasicentric, confluent, } \\
\text { lozenge-aliform, marginal }\end{array}$ & $\begin{array}{c}13 \\
(11-14) \\
1\end{array}$ & 3 & $\checkmark$ & fi-md \\
\hline Ocotea corymbosa & - & $\begin{array}{c}37 \\
(27-46) \\
4\end{array}$ & $\begin{array}{c}49 \\
(38-62) 7\end{array}$ & scanty* & $\begin{array}{c}13 \\
(9-16) \\
2\end{array}$ & 3 & - & fi \\
\hline Eriotheca gracilipes & a & $\begin{array}{c}114 \\
(87-149) \\
17\end{array}$ & $\begin{array}{c}24 \\
(18-32) 4\end{array}$ & diffuse, diffuse-in-aggregates & $\begin{array}{c}8 \\
(4-10) \\
2\end{array}$ & $2-3$ & - & md-co \\
\hline Microlepis oleifolia & a & $\begin{array}{c}46 \\
(24-95) \\
15\end{array}$ & $\begin{array}{c}55 \\
(36-70) 15\end{array}$ & scanty* & $\begin{array}{c}12 \\
(7-16) \\
3\end{array}$ & 3 & $\checkmark$ & fi \\
\hline Ficus guaranitica & - & $\begin{array}{c}80 \\
(60-113) \\
13\end{array}$ & $\begin{array}{c}10 \\
(6-18) \\
4\end{array}$ & bands & $\begin{array}{c}8 \\
(5-11) \\
2\end{array}$ & 1 & - & $\mathrm{co}-\mathrm{fb}$ \\
\hline Myrcia bella & a & $\begin{array}{c}56 \\
(39-80) \\
10\end{array}$ & $\begin{array}{c}44 \\
(32-60) 9\end{array}$ & diffuse-in-aggregates* & $\begin{array}{c}17 \\
(13-21) \\
3\end{array}$ & 2 & $\checkmark$ & fi-md \\
\hline Guapira noxia & - & $\begin{array}{c}60 \\
(45-89) \\
15\end{array}$ & $\begin{array}{c}16 \\
(12-23) 3\end{array}$ & vasicentric, confluent & $\begin{array}{c}6 \\
(4-7) \\
1\end{array}$ & 3 & - & $\mathrm{co}-\mathrm{fb}$ \\
\hline Ouratea spectabilis & - & $\begin{array}{c}62 \\
(47-87) \\
9\end{array}$ & $\begin{array}{c}26 \\
(16-35) 6\end{array}$ & $\begin{array}{l}\text { diffuse, diffuse-in- } \\
\text { aggregates, vasicentric }\end{array}$ & $\begin{array}{c}5 \\
(4-7) \\
1\end{array}$ & $1-2$ & $\checkmark$ & md \\
\hline Myrsine umbellata & a & $\begin{array}{c}42 \\
(23-58) \\
8\end{array}$ & $\begin{array}{c}76 \\
(46-100) 16\end{array}$ & scanty* and vasicentric & $\begin{array}{c}3 \\
(2-4) \\
1\end{array}$ & $1-2$ & $\checkmark$ & md-co \\
\hline Roupala montana & d & $\begin{array}{c}53 \\
(35-92) \\
13\end{array}$ & $\begin{array}{c}97(76-120) \\
16\end{array}$ & lines & $\begin{array}{c}2 \\
(2-3) \\
1\end{array}$ & 3 & - & $\mathrm{co}-\mathrm{fb}$ \\
\hline
\end{tabular}


TABLE I (continuation)

\begin{tabular}{|c|c|c|c|c|c|c|c|c|}
\hline \multirow[b]{2}{*}{ Specie } & \multirow{2}{*}{ GR } & \multicolumn{2}{|c|}{ Vessels } & \multirow{2}{*}{$\begin{array}{c}\text { Axial parenchyma } \\
\text { Type }\end{array}$} & \multirow{2}{*}{$\frac{\text { Rays }}{\mathrm{N}^{\circ} \text { per } \mathrm{mm}}$} & \multirow{2}{*}{$\frac{\mathbf{F b}}{\mathrm{WT}(\mu \mathrm{m})}$} & \multirow{2}{*}{ MI } & \multirow{2}{*}{$\mathbf{T x}$} \\
\hline & & $\varnothing(\mu \mathrm{m})$ & $\mathrm{N}^{\mathrm{o}}$ per $\mathrm{mm}^{2}$ & & & & & \\
\hline & & 36 & & & 16 & & & \\
\hline Tocoyena formosa & $\mathrm{a}$ & $(25-49)$ & $\sim 100$ & diffuse, diffuse-in-aggregates & $(13-19)$ & 3 & $(\checkmark)$ & fi \\
\hline & & $\begin{array}{c}6 \\
44\end{array}$ & & & $\begin{array}{c}2 \\
11\end{array}$ & & & \\
\hline Siparuna brasiliensis & $\mathrm{a}$ & $(29-59)$ & $\begin{array}{c}85(62-103) \\
15\end{array}$ & $\begin{array}{c}\text { diffuse-in-aggregates, few } \\
\text { lines }\end{array}$ & $(6-13)$ & 2 & $\checkmark$ & fi-co \\
\hline & & 8 & & & 2 & & & \\
\hline Styrax ferrugineus & $\mathrm{a}$ & $\begin{array}{c}67 \\
(48-92) \\
10\end{array}$ & $\begin{array}{c}56 \\
(45-66) 6\end{array}$ & $\begin{array}{l}\text { diffuse-in-aggregates, few } \\
\text { lines }\end{array}$ & $\begin{array}{c}8 \\
(6-10) \\
1\end{array}$ & 2 & $\checkmark$ & md \\
\hline & & 49 & & & 7 & & & \\
\hline Symplocos pubescens & $\mathrm{a}$ & $(38-60)$ & $>100$ & diffuse, diffuse-in-aggregates & $(4-9)$ & 2 & - & fi-md \\
\hline & & 5 & & & 2 & & & \\
\hline Vochysia tucanorum & e & $\begin{array}{c}87 \\
(73-117) \\
11\end{array}$ & $\begin{array}{c}16 \\
(10-23) 5\end{array}$ & $\begin{array}{l}\text { vasicentric, confluent, } \\
\text { lozenge-aliform, few bands }\end{array}$ & $\begin{array}{c}6 \\
(3-9) \\
2\end{array}$ & $1-2$ & $\checkmark$ & md-co \\
\hline
\end{tabular}

The species Lithrea molleoides, Gochnatia polymorpha, Tabebuia aurea, Terminalia glabrescens, Caryocar brasiliense, Anadenanthera peregrina var. falcata, Copaifera langsdorffi, Microlepis oleifolia, Ocotea corymbosa, Roupala montana, Tocoyena formosa, Styrax ferrugineus and Symplocos pubescens, has the first and second degrees of vitrification, seen just as a high level of brightness due to the cellular walls fusion.

Ruptures were present in Anadenanthera peregrina var. falcata, Caryocar brasiliense, Copaifera langsdorffi, Ficus guaranitica, Lithrea molleoides, Microlepis oleifolia, Myrsine umbellata, Ocotea corymbosa, Roupala montana, Siparuna. brasiliensis (Fig. 1i, f, j, o, a, n, s, 1, t, v, respectively).

Brightness was evident all species, being recognized more intensely in fibers with thick walls and in parenchyma cells with remaining contents.

Some special features were present in few species: scalariform perforation plates - Styrax ferrugineus and Symplocos pubescens (Fig. 2a, b, respectively); mineral inclusions - they might be seen in transversal surface (e.g. Siparuna brasiliensis); traumatic canals - Vochysia tucanorum (Fig. 1y, Fig. 2c); included phloem - Guapira noxia (Fig. 1q and Fig. 2d).
We present the charcoals micrographs in Figure 1, the magnifications used here is similar to a 10x magnification of hand lens. The most important details are in Figure 2.

\section{DISCUSSION}

The charcoals anatomy descriptions of the analyzed species, agreed with the wood descriptions of Sonsin et al. (2014) thereby we could confirm that by comparing our results with wood anatomy analyzes.

The first features that are evaluated in macroscopic analyses in charcoal are texture, brightness and vitrification. Comparing to wood, in charcoal we can't analyze color, odor and taste, and it is hard to obtain large sections to define grain precisely. Also, density is other property that should be measure carefully, because it depends on many factors as temperature and/or time of carbonization.

The axial parenchyma is the most important feature in wood identification (Metcalfe and Chalk 1950), though in charcoal is not always easy to observe - for example in the scanty (Ocotea corymbosa) and/or diffuse parenchyma (Lamanonia ternata). Banded parenchyma observed in Ficus guaranitica and different types of paratracheal 


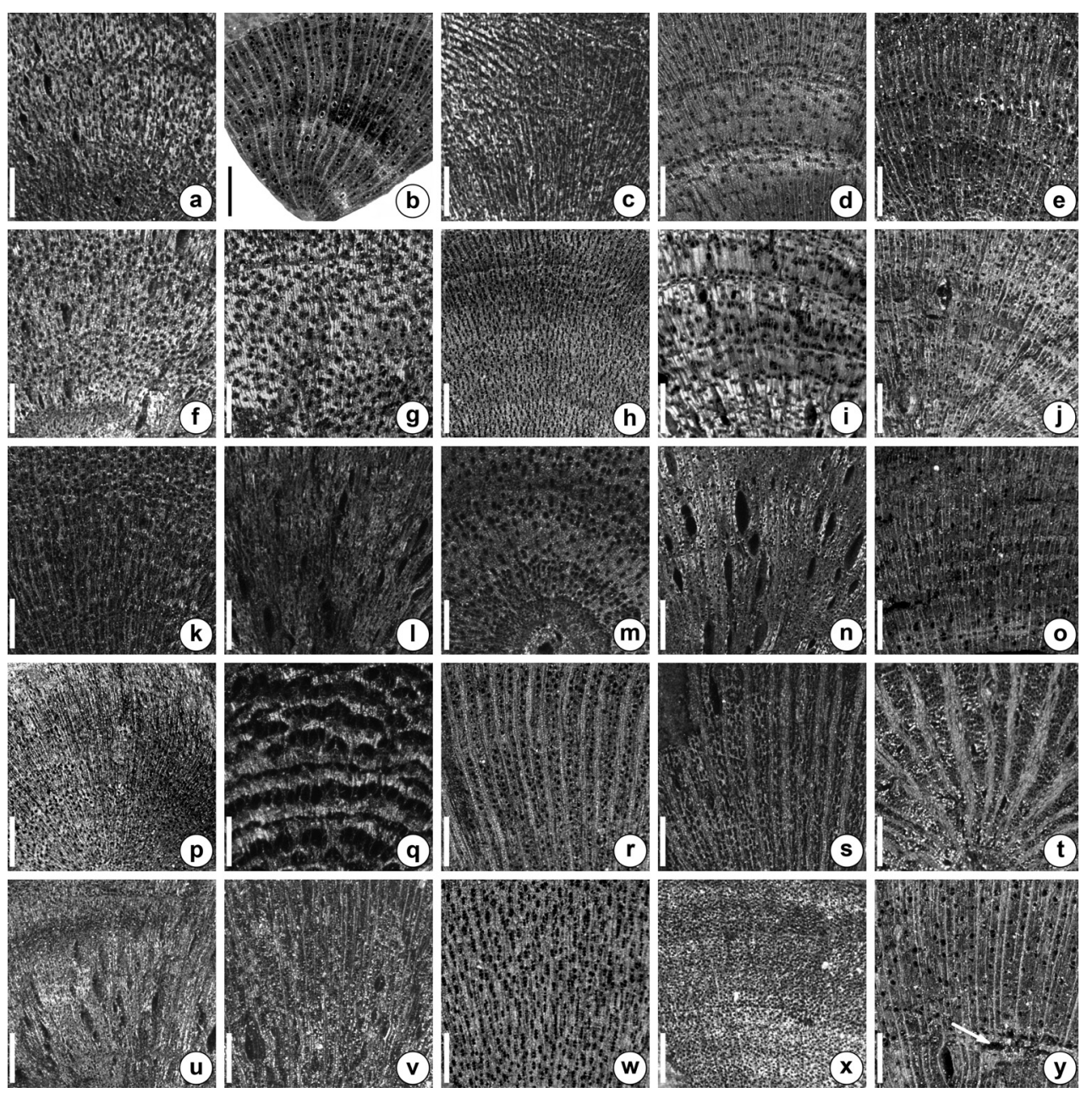

Figure 1 - Transverse section: a - Lithrea molleoides. b - Annona crassiflora. c - Gochnatia polymorpha. $\mathbf{d}$ - Tabebuia aurea. $\mathbf{e}$ - Cordia sellowiana. $\mathbf{f}$-Caryocar brasiliense. $\mathbf{g}$ - Terminalia glabrescens. $\mathbf{h}$ - Lamanonia ternata. $\mathbf{i}$ - Anadenanthera peregrina var. falcata. $\mathbf{j}$ - Copaifera langsdorffii. $\mathbf{k}$-Leptolobium elegans. $\mathbf{I}$ - Ocotea corymbosa. $\mathbf{m}$-Eriotheca gracilipes. $\mathbf{n}$-Microlepis oleifolia. $\mathbf{0}$ - Ficus guarnitica. $\mathbf{p}-$ Myrcia bella. $\mathbf{q}$ - Guapira noxia. $\mathbf{r}$ - Ouratea spectabilis. $\mathbf{s}-$ Myrsine umbellata. $\mathbf{t}$-Roupala montana. $\mathbf{u}$-Tocoyena formosa $\mathbf{v}$-Siparuna brasiliensis. $\mathbf{w}-$ Styrax ferrugineus. $\mathbf{x}$ - Symplocos pubescens. $\mathbf{y}$ - Vochysia tucanorum, arrow indicate traumatic cannals. Bars: $1 \mathrm{~mm}$.

parenchyma, in a general way are better seen because of the contrast with fibers.

In addition, vessel arrangement when present, as in Gochnatia polymorpha, frequency of vessels when in a greater quantity, as in Symplocos pubescens or lower quantity, observed in Vochysia tucanorum and, in some cases great differences in vessel diameter, associated with the other anatomical features, such as included phloem and sometimes with sensorial characteristics, give valuable information to distinguish families or even genera. Besides that, some features are known to occur just in few families or are only seen in higher magnifications (under microscope). This kind of characteristic can initially help the government agents to separate families or simple check the DOF ("document of forestry origin") and recognize that the species listed in the document are not the ones analyzed. For example, the presence of very large rays which are observe in 

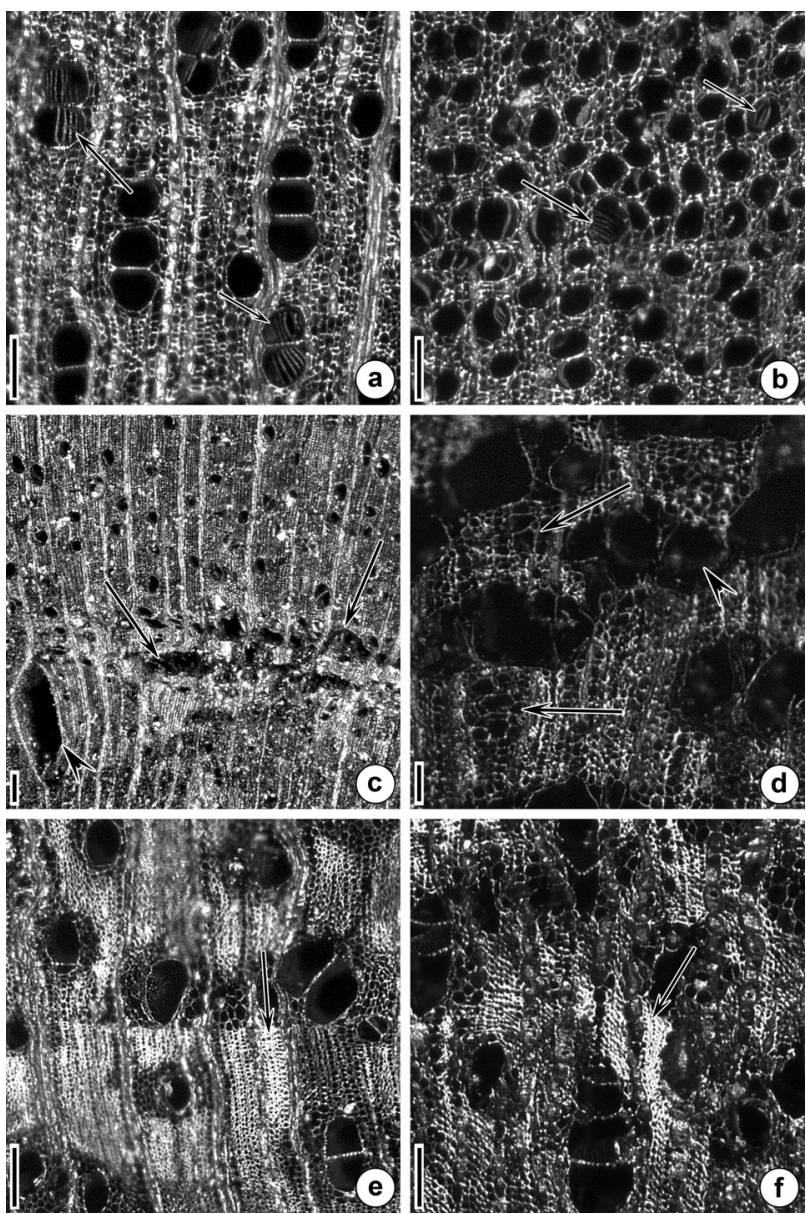

Figure 2 - Transverse section: a - Styrax ferrugineus, $\mathbf{b}$ Symplocos pubescens, arrow points to multiple perforation plate in vessels. c - Vochysia tucanorum, arrows indicate traumatic canals. d - Guapira noxia, large arrowhead point to included phloem, thin arrows indicate vessels. e - Anadenanthera peregrina var. falcata, $\mathbf{f}-$ Terminalia glabrescens, arrows point to vitrification. Bars: $100 \mu \mathrm{m}-\mathbf{a}, \mathbf{b}, \mathbf{d}, \mathbf{e}, \mathbf{f} ; 200 \mu \mathrm{m}-\mathbf{c}$.

transversal section, observed here in the families Annonaceae, Ochnaceae, Primulaceae, Proteaceae (Fig. 1b, r, s, t). Another example is the presence of the features as scalariform perforation plates, traumatic canals and included phloem can be very helpful to separate families and even genera when joint with other anatomical characteristics and are better observed in higher magnifications.

However, some of these anatomical features might cause some misguiding in charcoal identification for workers with less experience, such as the presence of included phloem in Guapira noxia. As there are several ruptures in the included phloem which seems like a deformed vessel in transverse section. Nevertheless, one can separate it because some vessels remain with their walls intact.

The growth rings were observed in $84 \%$ of the species of this study. According to the studies of Alves and Angyalossy-Alfonso (2000), Barros et al. (2006), Worbes $(1989,1999)$ and Worbes et al. (2003) Tropical Forest in general have growth rings. The previous authors studied species from Atlantic Forest, Amazon Rain forest, Semi-deciduous Forest in Brazil and Venezuela. The presence 
of growth rings demarcated by marginal bands of axial parenchyma and fiber zones were easier to observe in charcoals because of the large size of the cells. On the other side, marginal lines/bands of axial parenchyma and proximity of axial scalariform or reticulate parenchyma are not always easily observed. Sometimes the size of the sample or presence of ruptures might raise difficulties to observe or hide the growth rings in charcoal. For example, the growth rings in the wood of Ocotea corymbosa (Sonsin et al. 2014) could not be observed in the charcoal because of the high occurrence of ruptures - in both radial and axial parenchyma.

Most studied species have texture fine to medium, such as Gochnatia polymorpha, Cordia sellowiana, Lamanonia ternata, Copaifera langsdorffii, Leptolobium elegans, Myrcia bella and Symplocos pubescens. The characterization of texture in charcoal must be done carefully. It is due the possible ruptures caused by the process of manual breaking, e.g.: in species with large vessels or abundance of parenchyma. In such cases it might give an impression of coarser textures due to the irregularities in the surface. Therefore we recommend this analysis in charcoals recently broken with the surfaces as plain as possible.

The brightness in charcoal was observed in all studied species. Nevertheless, this feature is not of great value to identification because, in general, this feature is seen in most species. Also, even if in transverse section it is not so evident; the radial section is very shinny.

Vitrified elements were observed in most studied species, usually in degrees 1 and 2 (low brilliance-refractiveness; strong brilliance, respective1y). According to Marguerie and Hunot (2007), this feature can be recognized by fused cellular cells; and also by the contrast between the white color and dark-shades of gray. It is important to emphasize that if the charcoal is too vitrified, the cellular elements will be fused, causing a formation of a non-recognizable mass as observed by the previ- ous authors. Thus, environmental controllers might think that the sample is not of charcoal. Also, the white color can be observed in remaining content inside the cells and mineral inclusions.

As in wood, some qualitative features are best seen in higher magnifications, e.g. diffuse parenchyma; and others in lower, e.g. growth rings. In general, most of the data observed for the studied species, were well seen in lower magnifications. However, the practice is essential to develop the visual acuity for the identification of features on charcoal.

Despite of the studied species did not present a pattern for the occurrence of ruptures as commented in a previous work (see Gonçalves et al. 2014), we observed ruptures of the axial and ray parenchyma cells in some areas of few woods. These ruptures are expected as the parenchyma tissue is weak and it has thin walls.

\section{CONCLUSIONS}

This is the first paper with macroscopic characterization of charcoal's species from Cerrado. As in wood, we must analyze macroscopic before microscopic. The species analyzed had several differences in their anatomical structure and some of them are very unique and only observed in microscopic view. Otherwise, we strongly recommend higher magnifications for charcoal identification. The main anatomical features that are used to identify the charcoal genus are axial parenchyma type, vessels distribution and diameter and rays width. Also, it is important to emphasize that in real cases, the possibility of take samples from the field to the laboratory is not always an option. The present work might give directions to future identification of genera and/or species. Thus, it also provides knowledge for government agents to verify if the species listed in the documents (DOF) are the charcoal, by fast analyzing the sample itself. We hope this work can be use in practical activities to help the conservation of Cerrado's species. 


\section{ACKNOWLEDGMENTS}

The first author is supported by Coordenação de Aperfeiçoamento de Pessoal de Nível Superior (CAPES). This work is part of her $\mathrm{PhD}$ degree at the Universidade Federal do Paraná (Brazil).

\section{RESUMO}

O cerrado brasileiro é a savana mais rica do mundo. Também é um dos biomas mais ameaçados do país e um hotspot de prioridade de conservação. As principais causas do desmatamento no cerrado são as práticas agrícolas, pecuária e produção de carvão vegetal. Apesar da produção de carvão possuir menor impacto, seu consumo representa o desmatamento de $16.000 \mathrm{Km}^{2}$ do cerrado. Para a conservação do bioma é essencial aprimorar a fiscalização florestal. Assim sendo, neste trabalho apresentamos a caracterização macroscópica de carvão vegetal de 25 espécies do cerrado. Simulamos as condições reais de profissionais que realizam a fiscalização, usando ampliações de 10x, 25x e 65x. Igualmente, as micrografias dos carvões são todas das seções transversais devido à maior quantidade de informações anatômicas. Analisamos também a textura, o brilho, a vitrificação, rupturas e alguns caracteres especiais. As espécies apresentam várias diferenças em sua estrutura anatômica. Embora algumas sejam muito características, este trabalho não tem intenção de identificar carvões apenas por análises de macroscopia. Mas pode fornecer orientações para futura identificação de gêneros ou espécies. Também fornece conhecimento para os agentes governamentais poderem verificar os documentos de origem florestal por análise rápida de amostra do próprio carvão.

Palavras-chave: anatomia do carvão, conservação da natureza, fiscalização florestal, espécies nativas.

\section{REFERENCES}

ALVES ES AND ANGYALOSSY-ALFONSO V. 2000. Ecological trends in the wood anatomy of some Brazilian species I: Growth rings and vessels. IAWA J 21(1): 3-30.

ABRAF - ASSOCIAÇÃO BRASILEIRA DE PRODUTORES DE FLORESTAS PlantadAS. 2012. Anuário estatístico da ABRAF 2012: ano base 2011. Brasília: DF, Brasil, 149 p.
ABRAF - ASSOCIAÇÃO BRASILEIRA DE PRODUTORES DE Florestas PlantadAs. 2013. Anuário estatístico da ABRAF 2013: ano base 2012. Brasília: DF, Brasil, 142 p.

BARros CF, MARCON-FERREIRA ML, CALLADO CH, LIMA HRP, CUNHA M, MARQUETE O AND COSTA CG. 2006. Tendências ecológicas na anatomia da madeira de espécies da comunidade arbórea da reserva biológica de poço das antas, Rio de Janeiro, Brasil. Rodriguésia 57: 443-460.

BOTOSSO PC. 2009. Identificação macroscópica de madeiras: guia prático e noções básicas para o seu reconhecimento. Colombo: Embrapa Florestas, 65 p.

BRASIL. 2012. Balanço energético nacional 2012: ano base 2011. Ministério de Minas e Energia, Empresa de Pesquisa Energética: Rio de Janeiro, Brasil, 281 p.

BRASIL. 2013. Legislação brasileira sobre meio ambiente. Brasília: Câmara dos Deputados, Edições Câmara, Série e legislação 105, Caderno 3 - Temas Internacionais, 186 p.

Duboc E, Costa CJ, Veloso RF, Oliveira LS AND PALUDO A. 2007. Panorama atual da produção de carvão vegetal no Brasil e no Cerrado. Documentos/Embrapa Cerrados, $37 \mathrm{p}$.

FAO - FOOD AND AGRICULTURE ORGANIZATION OF THE United NATIONS. 2012. FAOSTAT: Forestry Data. [online] <http://faostat3.fao.org/home/index.html $>$. [Consulted: Mar 20, 2015].

FPL - FOREST PRODUCTS LABORATORY. 2010. Wood handbook - Wood as an engineering material. General Technical Report FPL-GTR-190. Madison, WI: U.S. Department of Agriculture, Forest Service, Forest Products Laboratory, $508 \mathrm{p}$.

GONÇALVES TAP, BALLARIN AW, NISGOSKI S AND MUÑIZ GIB. 2014. A contribution to the identification of charcoal origin in Brazil I - Anatomical characterization of Corymbia and Eucalyptus. Maderas, Cienc Tecnol (16): 323-336.

IBGE - INSTITUTO BRASILEIRO DE GEOGRAFIA E ESTATÍSTICA. 2010. Produção da extração vegetal e da silvicultura. Rio de Janeiro: IBGE 25: 50.

IAWA - INTERNATIONAL ASSOCIATION OF WOOD ANATOMISTS. Committee. 1989. List of microscopic features for hardwood identification. IAWA J 10(2): 219-332.

KLINK CA AND MACHADO RB. 2005. Conservation of the Brazilian Cerrado. Conserv Biol 19(3): 707-713.

KLINK CA AND MOREIRA AG. 2002. Past and current human occupation and land-use. In: Oliveira PS and Marquis RJ (Eds), The Cerrado of Brazil. Ecology and natural history of a neotropical savanna, p. 69-88.

LISTA DE ESPÉCIES DA FLORA DO BRASIL. Jardim Botânico do Rio de Janeiro. [online] <http://floradobrasil.jbrj.gov. br/>. [Consulted: Feb 29, 2015].

MARGUERIE D AND HUNOT JY. 2007. Charcoal analysis and dendrology: data from archaeological sites in northwestern France. J Archeol Sci (34): 1417-1433. 
METCALFE CR AND CHALK L. 1950. Anatomy of the dicotyledons. Oxford, Clarendon, 2 v. England, U.K., 1500 p.

MMA - MinistÉRIO DO MEIO AMBIENTE. 2011. Monitoramento do desmatamento nos biomas brasileiros por satélite - acordo de cooperação técnica MMA/IBAMA - Monitoramento do bioma Cerrado 2009-2010. Brasília: MMA, 65 p.

MUÑIZ GIB, NISGOSKI S, FRANÇA R AND SCHARdoZIN F. 2012. Anatomia comparativa da madeira e carvão de Cedrelinga catenaeformis Ducke e Enterolobium schomburgkii Benth. para fins de identificação. Scientia Forestalis 40: 192-297.

Myers N, MitTERMEIER RA, MitTERMEIER CG, FonseCA GAB AND KENT J. 2000. Biodiversity hotspots for conservation priorities. Nature 403: 853-858.
SONSIN JO, GASSON PE, MACHADO SR, CAUM C AND MARCATI CR. 2014. Atlas da Diversidade de Madeiras do Cerrado Paulista. $1^{\text {st }}$ ed., Botucatu: FEPAF 01, 423 p.

WORBES M. 1989. Growth rings, increment age of trees in inundation forests, savannas and a mountain forest in the Neotropics. IAWA J 10: 109-122.

WORBES M. 1999. Annual growth rings, rainfall dependet growth and long-term growth patterns of tropical trees from the Forest Reserve Caparo in Venezuela. J Ecol 87: 391-403.

WORBES M, StASCHEL R, ROLOFF A AND JUNK WJ. 2003. Tree rings analysis reveals age structure, dynamics and wood production of a natural forest stand in Cameroon. Forest Ecol Manag 173: 105-123. 